\title{
Hanging Out Phenomenon at Coffee Shop as An Environmental - based Economic tool in Covid- 19 Pandemic Era
}

\author{
Anjani Agusetyaningrum ${ }^{1 *}$ and Nurdien Harry Kistanto ${ }^{2}$ \\ ${ }^{1}$ Master of Literature Program, Faculty of Humanities, Diponegoro University \\ ${ }^{2}$ Master of Literature Program, Faculty of Humanities, Diponegoro University
}

\begin{abstract}
The cultural phenomenon of hanging out in coffee shops is now a phenomenon often found in big cities. This phenomenon is closely related to various circles, both upper and middle classes, with the age range of adolescents to adults. In the past, the phenomenon of hanging out in a coffee shop was only used as a meeting place for businessmen or office workers, but nowadays, hanging out has become a lifestyle for young people. This phenomenon is interesting to further research under the title "Hanging Out Phenomenon at Coffee Shop as An Environmental-based Economic tool in Covid-19 Pandemic Era". The method in this research is a qualitative method using data collected from observation and literature study. The authors shall describe the phenomenology of hanging out at coffee shops that could affect the environmental-based economy in the Covid-19 pandemic situation.
\end{abstract}

\section{INTRODUCTION}

Hanging out with colleagues is now an inherent lifestyle for both young people and adults. The phenomenon of hanging out at a coffee shop is no longer seen as just a professional need, such as meeting clients and so on. This phenomenon has formed a new popular culture among the people. The culture of hanging out in coffee shops is linear with the presence of coffee shops in Indonesia. This can be seen through independent research data conducted by Toffin (Dahwilani: 2019), which states that the number of coffee shops in Indonesia as of August 2019 has reached more than 2,950 outlets, an increase of almost three times compared to 2016, which was only 1,000 outlets.

This significant increase in the number of coffee shops also impacts the culinary business in Indonesia, which is increasingly advanced. This statement is supported by independent research data conducted by Toffin (Dahwilani: 2019), which states that the market value generated from the total coffee shop in Indonesia reaches IDR 4.8 trillion. That way, the culture of hanging out in coffee shops can be used as an environmental-based economic tool.

* Corresponding author: anjani.stya@.gmail.com 
Coffee shop as popular culture has succeeded in forming a new lifestyle pattern for the community, especially the modern lifestyle. Modern society, which is most highly mobile, makes coffee shops an alternative place for productive activities besides offices, campuses, and so on. The more needs of human life, the more demanding also an increase in lifestyle. Lifestyle is a lifestyle-related to how a person spends his time, for what is important with consideration of his interests and environment, and what people think about themselves and the environment (Priansa: 2017).

\section{DISCUSSION}

As explained in the introduction, the culture of hanging out in coffee shops has become a way of life for modern society, especially in big cities such as Jakarta, Bandung, Semarang, Jogja, Bali, and so on.

\subsection{The Cultural Phenomenon of Hanging Out in a Coffee Shop}

According to Geetz (1973), culture is considered a system of conception inherited from previous generations and expressed in symbolic form; with the help of human culture to communicate, perpetuate and develop knowledge and attitudes towards life. So it can be concluded that culture includes all aspects of human life and is usually hereditary, which can be preserved to its successors.

The definition of culture, which is quite complex, is a challenge in itself, especially in this day and age. Geertz said (1960: 4), "cutting the concept of culture into a sharp, specific, and theoretically stronger concept is a significant theme in the theory of modern anthropology. Hanging out culture is a culture that has existed since ancient times, and its existence is frequent times underestimated by most people. The culture of hanging outgrows on the factor of Indonesian society who likes to socialize with one another. Although it is often underestimated, this culture of hanging out can increase creativity in thinking and working. This can be seen from the behaviour of people who choose cafes to find inspiration, whether in working on projects, discussing with clients, or doing class assignments.

This culture of hanging out in coffee shops has become a lifestyle that cannot be separated for teenagers and adults. Alfred Adler, a psychologist, argues that a lifestyle is a group And behaviour that has meaning for individuals and other people at any one time in a place, including social relations, consumption of goods, entertainment, and ways of dressing. The behaviours that appear in the lifestyle are a mixture of habits, mutually agreed ways of doing something, and planned behaviour (Priansa: 2017). Through this understanding, it can be concluded that a lifestyle is a person's way of living his life in terms of appearance, social relationships, and thoughts attached to him.

The phenomenon of hanging out in coffee shops is also due to globalization, which has caused western lifestyles to enter into Indonesian culture. This can be seen from the number of cafes that name their menu in English. For the managers of the western-style coffee shop attached to the cafe, it is the main attraction for consumers. Through the number of people who open a coffee shop business, they no longer only sell coffee itself but rather their lifestyle, simply serving delicious coffee or other drinks and a touch of aesthetic atmosphere or usually referred to as instagramable, able to make visitors spend hours and hours of their time in the coffee shop. 


\subsection{Coffee Shop as An Enviromental- based economic Tool During Pandemic Covid-19 Era}

The Covid-19 virus had a tremendous impact on human life, starting from social interactions, economics, and even people's lifestyles. COVID-19 caused a major crisis for the business world such as hotels, restaurants and bars(Kim \& Lee, 2020). Coffee shops as part of the culinary business experienced an economic impact caused by the Covid-19 pandemic, but this only affected the beginning of the pandemic in Indonesia, which was around February.

During the Covid-19 pandemic, which imposed restrictions on activities outside the home, several coffee shops were sluggish due to decisions taken by the government. However, in the second quarter, the policies taken by the government regarding the new normal era gave a breath of relief to coffee shop managers. Coffee shop owners are allowed to re-operate the café on condition that they implement health protocols. Despite the pandemic, the coffee shop business is still able to survive compared to the hotel business or clothing retail. This statement is supported by research data conducted by Brodjonegoro (2020), explaining that in the third quarter of 2020 it was stated that due to the Covid-19 pandemic, the commodity prices for robusta coffee and arabica coffee weakened to USD 2.8 (Rp. 41,734) and USD respectively. 1.5 (Rp. 22,357) per kilogram. The decline in commodity prices at the retail consumer level did not decline sharply like the price of non-agricultural commodities because the distribution process of coffee products did not experience significant obstacles.

Based on the data presented above, it can be seen that the coffee shop business has experienced a decline due to the Covid-19 pandemic, but this decline is not too significant compared to other businesses besides coffee shops. The culture of hanging out in coffee shops is able to survive during the Covid-19 pandemic, even the phenomenon of hanging out in coffee shops has a positive impact on the wheels of the economy in Indonesia.

\section{CONCLUSION}

The phenomenon of hanging out in coffee shops has become a new culture in modern society, especially in big cities. People in urban areas feel that hanging out in coffee shops has become a lifestyle for young people today. By hanging out at the coffee shop, visitors feel that they have a comfortable place to channel their creativity in the form of ideas and works. Not infrequently, the coffee shop is also used as a professional place such as meetings with clients, distance learning activities, etc.

The culture of hanging out in coffee shops is also able to survive the Covid-19 pandemic; this can be seen based on data obtained by Brodjonegoro (2020), stating that in the third quarter of 2020 it was stated that due to the Covid-19 pandemic, the commodity prices of robusta coffee and arabica coffee weakened to USD 2.8 (Rp. 41,734) and USD 1.5 (Rp. 22,357) per kilogram, respectively. The decline that occurred in the agricultural sector was not too sharp compared to other sectors. So it can be concluded that the phenomenon of hanging out in coffee shops can be used as an environmental-based economic tool during the Covid-19 pandemic. 


\section{References}

1. Brodjonegoro, B. P. 2020). Perkembangan Ekonomi Indonesia dan Dunia Triwulan II 2019 (Vol. 3, Issue 4). Retrived from: bappenas.go.id.

2. Dahwilani, Dani M. 2019. Data dan Fakta Tren Menjamurnya Kedai Kopi Kekinian di Indonesia. Retrived from: inews.id.

3. Geertz, Clifford. 1973. The Interpretation of Culture. Chicago and London: The University of Chicago Press

4. Kim, J., \& Lee, J. C. 2020. Effects of COVID-19 on preferences for private dining facilities in restaurants. Journal of Hospitality and Tourism Management, 45(July), 6770. Retrived from: doi.org/10.1016/j.jhtm.2020.07.

5. Priansa, Donni Juni. 2017, Perilaku Konsumen dalam Persaingan Bisnis Kontemporer. Bandung : Alfabeta, 185. 